\section{India parcels out its energy problems}

\section{from Narender Sehgal}

RECENT changes in the central council of ministers, following a cabinet reshuffle, have resulted in the creation of a separate Ministry for Energy, to be headed by a minister of state (slightly lower in status than a full fledged cabinet minister). This, however, does not mean that all subjects relating to energy have been brought under one roof. Far from it; as of now, only 'power' (from the erstwhile Irrigation and Power Ministry) and 'coal' (from 'mines' which until now had been under the charge of the Ministry of Steel and Mines) have been assigned to the new ministry.

Fears are already being voiced about the administrative problems that may arise from the change. For example, much of the hydroelectric power produced $(37 \%$ of the total generated in India by all means) is tied to irrigation projects, hence their association in a single ministry. (Irrigation will now form part of the Ministry of Agriculture.)

Oil, which accounts for $50 \%$ of India's entire consumption of energy derived from commercial sources, remains, as before, part of Petroleum and Chemicals under the charge of a cabinet minister.

The diversity of coal users (railways and the steel and fertiliser industries, for example) presents an additional problem of administration and coordination. It remains to be seen if it is possible to retain all matters concerning coal within the ambit of the newly created Ministry of Energy.

Then there is atomic energy which remains under the direct control of the Prime Minister. In this area of increasing importance, Shrimati Gandhi has been in the past assisted by Shri K. C. Pant who will continue in this role even after he has taken charge of the new Ministry of Energy.

On the basis of the past record of co-operation and coordination between various ministries, it is not possible to feel overly enthusiastic about this new attempt to solve India's grave and growing energy problems.

- India is known to have uranium in only small amounts. Known deposits, at present rates of production and consumption (with due allowance for planned future uses) would last no longer than some 30 years. On the other hand, China is understood to possess uranium in fair abundance in relation to her immediate and long term needs. One would think, then, that China could not possibly have any use for Indian uranium.
No so. Men arrested by the Bihar police recently, with varying quantities of uranium in their possession, have revealed that the stolen metal was meant to be smuggled to China through Nepal and that another 100 kilograms or so was awaiting disposal at various places in Bihar. An editor of the Hindi daily at Patna, engaged in investigating the smuggling operations and possessing some related documents, was reportedly murdered and relevant documents stolen by the apparently well organised gang of uranium smugglers, just before the newspaper was about to publish the story.

The uranium in question was stolen from the Jadugoda mines near Jamshedpur in Bihar. While investigations and more arrests are continuing, the view is gaining ground that the motivation behind the Chinese interest in Indian uranium may have to do with her desire to weaken or slow India's atomic enengy programme.

\section{Weather watch down under}

\section{by John Gribbin}

THE Commonwealth Meteorology Research Centre, which was set up in 1969 with a five year lease of life, has recently been reconstituted and provided with an extension for a further five years, under the auspices of the Australian government. Now the Australian Numerical Meteorology Research Centre (ANMRC), this Melbourne based operation is playing a key role in studies of the problems of meteorological research in the southern hemisphere.

These problems are formidable indeed. Because of the great proportion of ocean in the south the observational network is far from complete; in addition, the distribution of what land there is means that population in the southern hemisphere is concentrated in the tropical and near tropical regions, north of $40^{\circ} \mathrm{S}$. And far less is known about the behaviour of weather systems at these latitudes than at extratropical latitudes.

During its first five years of existence under the "Commonwealth" label, the centre was closely allied with the Global Atmospheric Research Programme (GARP), and this spirit seems likely to continue. In July of this year, when the centre was renamed, the Australian government affirmed support for the next five years, with research objectives defined in the following terms:

"The work of the Centre consists of studies of the behaviour of the earth's atmosphere, with emphasis on general circulation, directed towards improvement in the accuracy and timescale of weather forecasting, and towards improvement in understanding the distribution and variations in climate on the earth."

The work at the ANMRC is, as its name suggests, strongly orientated towards computer studies, with facilities available on the IBM $360 / 65$ at the World Meteorological Centre in Melbourne (this centre is the southern counterpart of the two WMCs in Washington and Moscow, the three forming part of the World Weather Watch). With the aid of modern satellite photography, many of the handicaps resulting from the shortage of observing stations in the south can be overcome; satellite and other data are combined in mathematical models of atmospheric flow which have already produced reasonable forecasts for one to four days ahead. Improvements are likely to come on two fronts: through introducing more representations of physical processes into the model (better 'skill'); and through refining the numerical methods used (better 'efficiency').

In global terms, the Australian work is particularly interesting because it offers an alternative mathematical approach to some of the problems which beset meteorologists attempting to produce global models. So far, such models have encountered difficulty because of problems near the poles, and although progress is being made there is a need for different approaches to resolve the difficulties. The ANMRC has been working with the so-called 'spectral method', which involves representing the atmospheric variables by a truncated series of spherical harmonics, and with a combination of spectral techniques and grid techniques, which they refer to as a 'semi-spectral' or Fourier model.

In a draft version of part of the 1974 Annual Report of the ANMRC (as yet unpublished) it is stated that "a significant proportion of the operational products [sic] now issued by the National Meteorological Analysis Centre of the Australian Bureau of Meteorology are numerically derived", although "manual intervention" is still an important part of the forecasting process. The draft goes on to say that the Fourier model is now also proving useful in basic atmospheric research, and is helping to provide an insight into the dynamics of the stratosphere and mesosphere; in future years, as the research programme matures, the ANMRC sees a greater emphasis on such problems as the influence of volcanic debris and of anomalies in sea surface temperatures on climatic change. 